$$
\text { DOE } / P C / 888.55--T 3
$$

ENZYMATIC DESULFURIZATION OF COAL

$\mathrm{DOE} / \mathrm{PC} / 88855--\mathrm{T} 3$

\title{
First Quarterly Report
}

DE92 006533

Holometrix Report No. 2458

Holometr1x Project No. DOE-12

DOE Contract Number DE-AC22-88PC88855

\author{
Submitted to: \\ Mr. Ellas George \\ Project Manager, \\ U.S. Department of Energy \\ P.0. Box 10940, Building 922 \\ Chochrane Mill Road \\ Pittsburgh, Pennsylvania 15236-0940
}

October 7, 1988

\author{
Prepared by: \\ Judith K. Marquis, Ph.D. \\ Boston. University School of Medicine \\ and \\ Judith P. Kitche11, Ph.D. \\ Holometrix, Inc.
}

\author{
Submitted by: \\ HOLOMETRIX, INC. \\ 99 Erie Street \\ Cambridge, Massachusetts 02139
}

Telephone (617) 868-8050

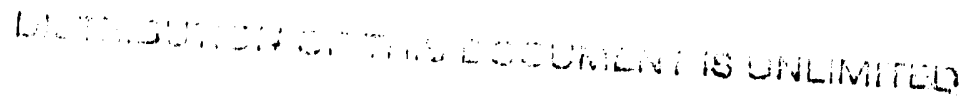


ENZYMATIC DESULFURIZATION OF COAL

F1rst Quarterly Report

Holometrix Report No. 2458

Holomitrix Project No. DOE-12

DOE Contiact Number DE-AC22-88PC88855

Submitted to:

Mr. Elias George

Project Manager,

U.S. Department of Energy

P.0. Box 10940, Bullding 922

Chochrane Mill Road

Pittsburgh, Pennsylvania 15236-0940

October 7, 1988

Prepared by:

Judith K. Marquis, Ph.D.

Boston University School of Medicine and

Judith P. Kitchell, Ph.D. Holometrix, Inc.

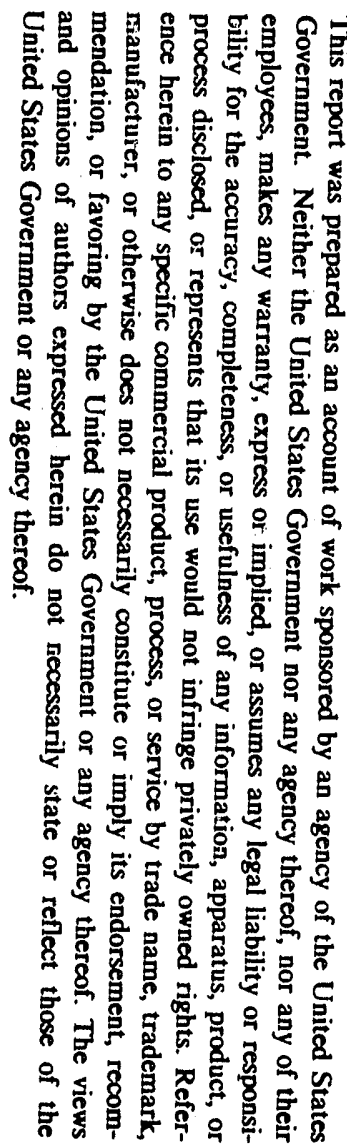

Submitted by:

HOLOMETRIX, INC.

99 Erie Street

Cambridge, Massachusetts 02139

Telephone (617) 868-8050 


\section{Section}

\begin{tabular}{|c|c|}
\hline 1 & INTRODUCTION \\
\hline $\begin{array}{l}1.1 \\
1.2\end{array}$ & $\begin{array}{l}\text { Program Overview } \\
\text { Summary of Results }\end{array}$ \\
\hline 2 & EXPERIMENTAL RESULTS AND DISCUSSION \\
\hline .1 & $\begin{array}{l}\text { Work With Horseradish Peroxidase } \\
\text { Work With Laccase }\end{array}$ \\
\hline $\begin{array}{l}2.1 \\
2.2 \\
2.3 \\
2.4\end{array}$ & $\begin{array}{l}\text { Work With Standard Substrate in Buffer } \\
\text { Work With Standard Substrate in Organic Media } \\
\text { Work With Ethylphenylsulfide [EPS] in Organic Media } \\
\text { Work With Dibenzothiophene in Organic Medla }\end{array}$ \\
\hline .4 & $\begin{array}{l}\text { Gas Chromatography as a Means of Monftoring Substrate } \\
\text { Level and Reaction Products } \\
\text { Spectrophotometric Analysis of DBT and the " } 4 \mathrm{~S} \text { " Pathway } \\
\text { Development of Microbial Sources of Enzyme }\end{array}$ \\
\hline
\end{tabular}




\section{LIST OF FIGURES}

F1gure

$\underline{\text { Page }}$

1.1 The "4S" Pathway

2.1 Laccase Assay Vs. Syringaldazine in Buffer 7

2.2 Laccase Assay Vs. Syringaldazine in 5\% Aqueous DMF 10

2.3 Laccase Dissolved in 5\% Buffer/Dioxane With Syringalda- 12 zine as Substrate

2.4 Laccase Suspended in 5\% Buffer/DMF With EPS as Substrate 15

2.5 Laccase Suspended in 5\% Buffer/Dioxane With DBT as 17 Substrate

2.6 DBT in 5\% Buffer/Dioxane Gas Chromatography Calibration 18 Curve

2.7 Gas Chromatographic Separation of DBT and Oxidation 20 Products

2.8 Representative UV Spectra of DBT (A), DBT Sulfoxide (B), 21 DBT Sulfone (C), and o,o-Biphenol (D)

\section{LIST OF TABLES}

Table

Page

2.1 Enzymatic Activity of Horseradish Peroxidase Using Standardized Assay Systems in Hydrous Solvent Matrices

2.2 Solubility Studies - Concentrations of Laccase in Varlous Media

2.3 Preliminary Growth Data for Eight Week Enrichment Cultures Grown Exclusively on Organic Sulfur Feedstock 


\section{Section 1}

\section{INTRODUCTION}

\section{$1.1 \quad$ Program Overview}

Numerous studies are underway to develop biological processes for the removal of both mineral and organic sulfur from coal. To remove the organic sulfur which is covalently bound, various research groups are studying strains of bacteria and fung 1 which can be induced to utilize organic sulfur compounds as feedstocks.

A consideration of industrial scale-up and operational requirements indicates that microbial ingestion of sulfur may produce technical difficulties that can be circumvented by the use of extracellular (i.e., secreted) or purifled enzymes rather than whole microbes. For example, a 20,000 ton/day coal process would require about 200 tons of microbes to achieve a 1 percent removal of organic sulfur. If this sulfur is incorporated into the microbe, the daunting task of separating the fuel from the sulfur-enriched organisms presents added cost and process requirements.

Our current efforts to develop clean coal technology, emphasize the advantages of enzymatic desulfurization techniques and have specifically addressed the potential of using partially-purified extracellular microbial enzymes or commercialiy available enzymes. Our work is focused on the treatment of "model" organic sulfur compounds such as dibenzothiophene (DBT) and ethylphenylsulfide (EPS). Furthermore, we are designing experiments to Facilitate the enzymatic process by means of a hydrated organic solvent matrix.

During the first quarter of this project, our laboratories have pursued primarily the multi-step, enzymatic breakdown of DBT and the development of the Klibanov-type hydrate solvent reaction system. Previous studies with the aromatic sulfur compound DBT have shown that there are two general biological pathways for the oxidative breakdown of this compound. In the reaction most frequently observed in microblal oxidative pathways, 
DBT is oxidized at a ring carbon, and the reaction is accompanied by a considerabie decrease in the free energy of the compound. Our work is focused on oxidation at the sulfur with consequent liberation of inorganic sulfate. The identification of this multi-step ("4S") reaction pathway has led us to examine each of the oxidfzed sulfur intermediates, as well as the desulfurized product. These compounds are illustrated in Figure 1.1.

\subsection{Summary of Results}

This report covers the period May 5, 1988 to September 30, 1988 .

The first month of this period was directed primarily at rewriting and reorganizing the workscope in collaboration with both the technical and administrative projects managers of DOE.

Our technical progress can be summarized as follows. We have worked with laccase (from Sigma) in buffer and in aqueous organic solvents. The aqueous system is a standard assay provided by Sigma, with syringaldazine [SYN] as substrate. This assay is necessary to measure the baseline activity of each batch of laccase. The assay method relies on an increase in absorbance at $530 \mathrm{~nm}$, which coincides with lambda maximum of the assay product. We found that the reaction can also be monitored at $352 \mathrm{~nm}$, the lambda maximum of the substrate, which decreases as a function of reaction time.

Having established the activity of our laccase in buffer, many tests of activity in hydrated dioxane and hydrated DMF media were made. In both solvents, conditions were found for obtaining laccase activity against SYN. It does appear, however, that the activity is decreased substantially within a few hours when the enzyme is stored in concentrated solution at room temperature. We have also obtained slight evidence of activity of laccase against dibenzothiophene [DBT] and [EPS] in both hỵrated dioxane and hydrated DMF.

We have similarly worked with horseradish peroxidase in aqueous and hydrated organic solvents. One-hundred percent ac:ivity against standard substrate is retained in hydrated DMF. We have also investigated spectral and chromatographic methods of identification of the compounds in the "4S" pathway. 


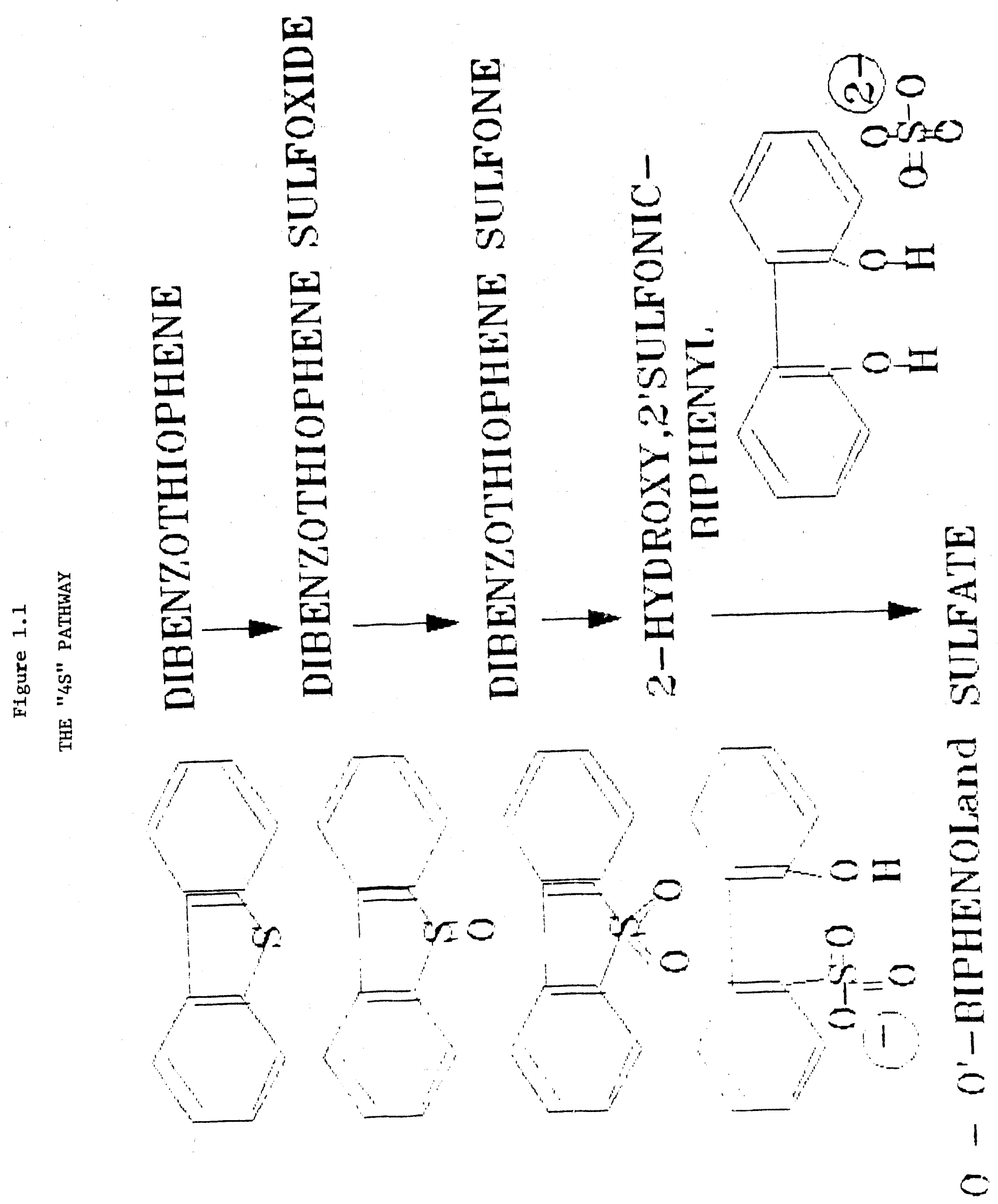




\section{SEะtion 2}

\section{EXPERIMENTAL RESULTS AND DISCUSSION}

\subsection{Work With Horserad1sh Peroxidase}

In Dr. Marquis' laboratory, a summer student worked for six weeks on the project, then left earlier than planned to go back to school. A new senior technician, Robert MacCallum, was hired in early September and has proved to be a tremendous asset to this project. The enzyme studies have progressed markedly since Mr. MacCallum joined this project and we anticipate that he will be a valuable member of our team. In addition, a new graduate student in Dr. Marquis' laboratory, Lorl Katz, will be foining the project in January.

Our initial studies with the hydrogen peroxide-horseradish peroxidase $\left(\mathrm{H}_{2} \mathrm{O}_{2}-\mathrm{HRP}\right)$ enzymatic system in dioxane were run despite the early finding that the enzyme exhibits only 10 to 20 percent of control activity in a hydrous dioxane medium (set Table 2.1). We were encouraged to proceed with the dioxane matrix, however, because UV spectra exhibited an apparent increase in the polarity of DBT evident as a loss of the low wavelength peaks (215 nm and $256 \mathrm{~nm}$ ) of the spectrum. Recently, we found that $\mathrm{H}_{2} \mathrm{O}_{2}$ alone can produce similar shifts in the DBT spectrum and have to date falled to elicit enzymatic oxidation. Currently, we are varying experiments conditions (buffer-solvent ratio, levels of enzyme and/or substrate) to further explore the dioxane matrix.

As shown in Table 2.1, HRP activity is very well maintained in a hydrated dimethylformamide (DMF) matrix. Our studies in DMF have just begun at the time of this report.

\subsection{Work With Laccase}

\subsubsection{Work With Standard Substrate in Buffer}

We obtained from Sigma the standard assay method for laccase. The method is as follows. 
Table 2.1

\section{ENZYMATIC ACTIVITY OF HORSERADISH PEROXIDASE \\ USING STANDARDIZED ASSAY SYSTEMS IN HYDROUS SOLVENT MATRICES}

\begin{tabular}{|c|c|}
\hline ASSAY SYSTEM & $\begin{array}{c}\text { ENZYME ACTIVITY } \\
(\% \text {-Control })\end{array}$ \\
\hline Standard Buffer & $\begin{array}{l}\text { HORSERADISH } \\
\text { PEROXIDASE }\end{array}$ \\
\hline Dioxane + $5 \%$ Buffer & $100 \%$ \\
\hline DMF + $5 \%$ Buffer & 10 to $20 \%$ \\
\hline
\end{tabular}

DMF $=$ dimethy 1 formamide

Buffer $=2.5 \mathrm{mM}$ tris, $\mathrm{pH} 6.2$, for HRP studies

Standard Buffer for HRP = antipyrine/phenol substrate in peroxide/acetate buffer reagent system. This HRP assay procedure monitors the development over time of color at $510 \mathrm{~nm}$ with antipyrine in phenol as the substrate $\mathrm{H}_{2} \mathrm{O}_{2}$ as co-factor. The reaction is linear for at least 20 minutes under the conditions of assay. Enzyme activity in solvent plus buffer was calculated as $\Delta O . D$./minute and expressed as \%-control. 
(1) Dissolve laccase in water (concentration not given); we made solutions of about $2 \mathrm{mg} / \mathrm{ml}$ laccase and also $10 \mathrm{X}$ and $100 \mathrm{X}$ dilutions.

(2) Prepare $0.1 \mathrm{M}$ (potassium) phosphate buffer at $\mathrm{pH} 6.5$.

(3) Dissolve $7 \mathrm{mg}$ of syringaldazine [SYN] in $100 \mathrm{ml}$ of methanol $\left(1.94 \times 10^{-4} \mathrm{M}\right)$.

(4) $3 \mathrm{mls}$ of buffer are warmed to $30^{\circ} \mathrm{C}$ in a test tube, $1 \mathrm{ml}$ of enzyme solution (kept at room remperature) is added, and the tube is covered and inverted several times to mix.

(5) $0.5 \mathrm{ml}$ of the SYN solution (prewarmed to $30^{\circ} \mathrm{C}$ ) is added and the solution is mixed again by tube inversion.

(6) At 5 minutes, a sample is taken and the absorbance is read at $530 \mathrm{~nm}$ vs. a solution of buffer and enzyme (the enzyme does not have absorbance at this wavelength). Using this method, one activity unit is that amount of enzyme which gives an increase in absorbance at $530 \mathrm{~nm}$ of $0.001 /$ minute.

To assess the correlation of decrease in absorbance at the lambda maximum of syringaldzine (352 nm in buffer) with the increase in absorbtion at $530 \mathrm{~nm}$, the assay was repeated, making measurements at 352 and $530 \mathrm{~nm}$ every 10 seconds for 10 minutes. The results are shown in graph form in Figures 2.1a and 2.1b. It can be seen that the assay is linear over the ten minute period. The slope of the appearance of product (A530) [1.2 X $10^{-3}$ absorbance units/minute] is a little more than twice as large as the slope of the disappearance of substrate $\left[-5.1 \times 10^{-4}\right.$ absorbance units/minutel, probably due to the differences in extinction coefficients for substrate and product. The ability to correlate the decrease of UV absorbance with activity is important because the assay product does not have the high absorbance in the visable range in the organic media which are to be utflized.

\subsubsection{Work With Standard Substrate in Organic Media}

Syringaldazine [SYN] dissolves in both hydrated dioxane and hydrated DMF. The solutions are stable at elevated temperatures $\left(30^{\circ} \mathrm{C}\right)$ as seen by unchanging spectra with maximum absorbance at $360 \mathrm{~nm}$ in the DMF and $356 \mathrm{~nm}$ in the dioxane. The solutions are transparent above $500 \mathrm{~nm}$. 
Figure 2.1

LACCASE ASSAY VS SYRINGALDAZINE IN BUFFER

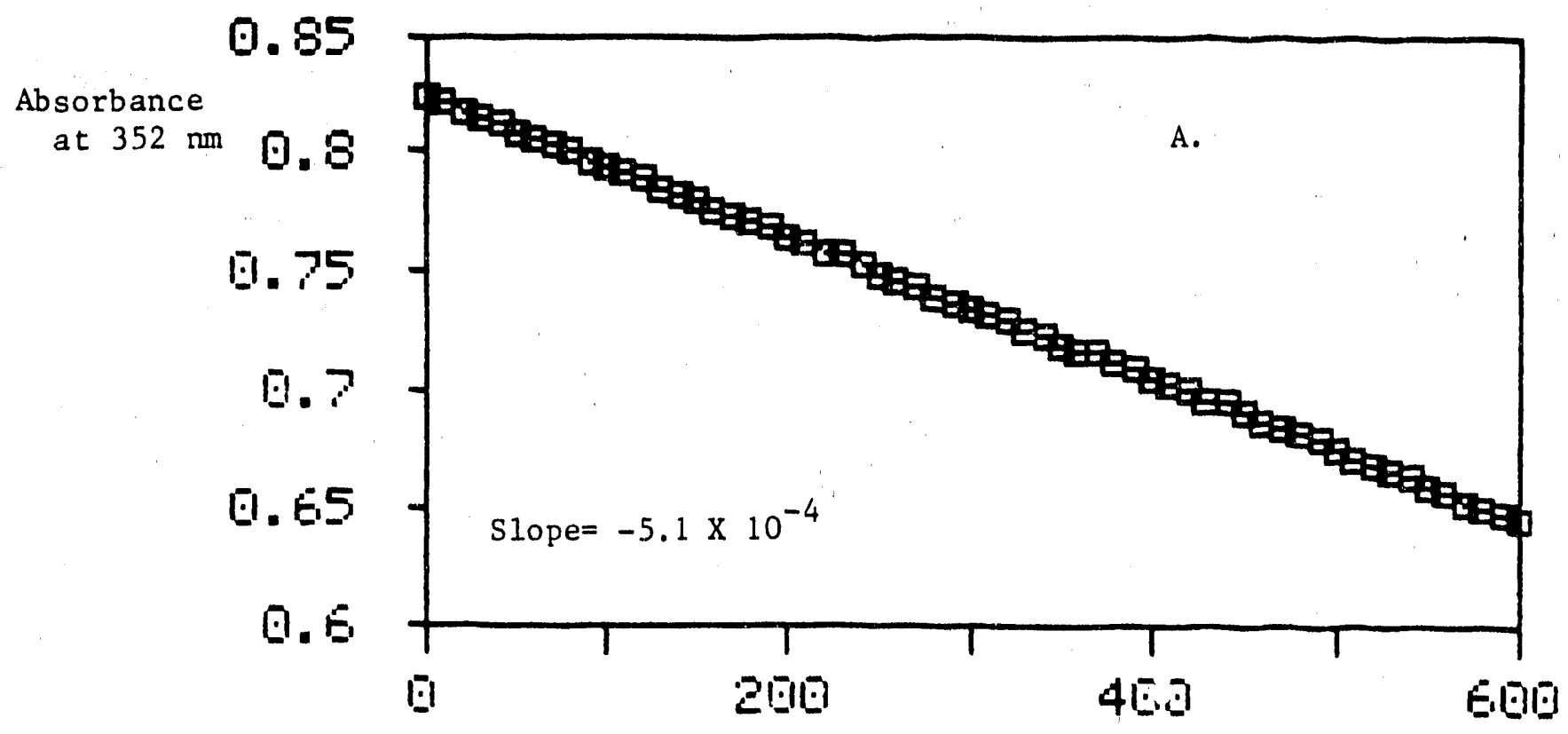

TIME (SELONDS)

B.

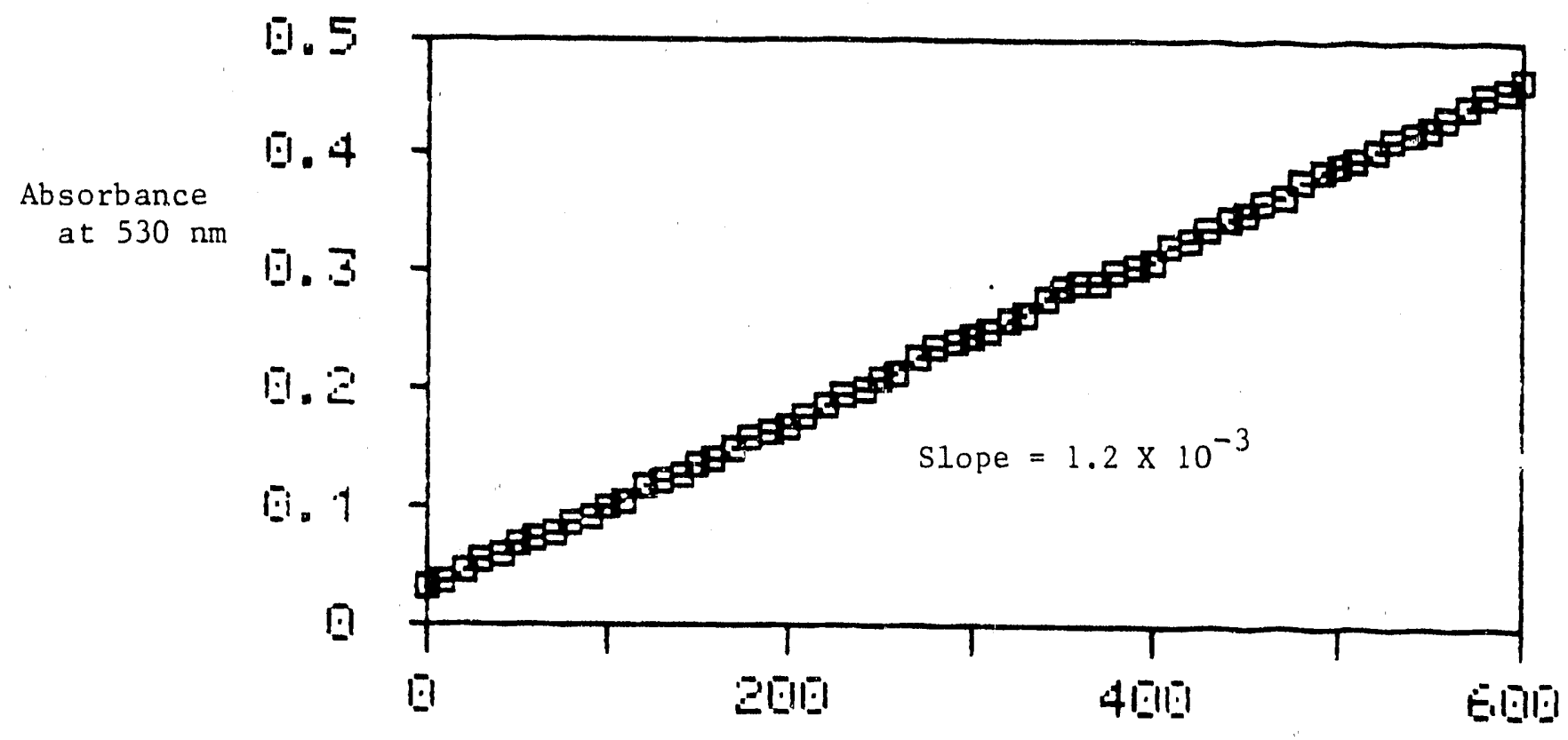

TIME (SECOHLS) 
The enzyme, when placed directly (dry method) in hydrated DMF or dloxane, does not all dissolve. When enzyme is first suspended in buffer or water (wet method) and this solution is then added to the organic solvent, a clear or nearly clear solution is obtained. The amount of activity in these suspensions or solutions is not necessarily a function of clarity, however, the suspensions have been found to contain active enzyme. Several combinations of media and methods of preparation of laccase reagent have been employed and these are summarized in Table 2.2.

A preliminary assay method, following earlier work at Holometrix with horseradish peroxidase, was first utilized with laccase in hydrated organic solvents. For example: an aliquot of $12.5 \mathrm{mg}$ of laccase was added dry to $5 \mathrm{ml}$ of 5 percent aqueous DMF. There was undissolved material in the container and a portion of it was filtered through a $0.45 \mu$ filter. An aliquot of $0.1 \mathrm{ml}$ of enzyme solution was mixed with $2.4 \mathrm{ml}$ aqueous DMF in a cuvette, then $0.5 \mathrm{ml}$ of syringaldazine in the aqueous DMF was added. After mixing, the cuvette was placed in the UV/VIS spectrophotometer and kept at $30^{\circ} \mathrm{C}$ with a circulating water bath. Scans were made from 220 to $600 \mathrm{~nm}$ every 10 minutes. It was found that no change in absorbance occurred above 500 , however, the absorbance at $360 \mathrm{~nm}$ did decrease with time and the shape of the scan at the lower wavelengths changed over a two hour period.

The test was run twice; the enzyme solution was kept at room temperature for several hours in between runs. In both cases there was an apparent reaction (judging from decrease at $360 \mathrm{~nm}$ ) but the rates of decrease were vastly different, the second test rate was about $1 / 100$ th of the first. It appeared that the enzyme activity was decreased in the course of the day. The results of the two tests are shown in Figures 2.2a and $2.2 b$. It is interesting to note that in this assay the rate of the reduction of lambda maximum of substrate was $-2.3 \times 10^{-3}$ units/minutes, whereas in the buffered system the rate of reduction as $-1.2 \times 10^{-3}$ units/minute. This is significant because in the organic system far less enzyme was presumably utilized because it did not all dissolve.

In all subsequent laccase work, the standard assay procedure given in Section 2.2 .1 was modified by substituting hydrated dioxane or hydrated DMF for all other solvents (e.g., $3 \mathrm{ml}$ media, $1 \mathrm{ml}$ enzyme in media, 
Table 2.2

SOLUBILITY STUDIES - CONCENTRATIONS OF LACCASE IN VARIOUS MEDIA

\begin{tabular}{|c|c|c|c|c|}
\hline \multirow{3}{*}{$\begin{array}{l}\text { WATER OR BUFFER } \\
\text { (type/percent) }\end{array}$} & \multicolumn{4}{|c|}{$\begin{array}{l}\text { AMOUNT } \\
(\mathrm{mg} / \mathrm{ml})\end{array}$} \\
\hline & $\overline{D M F}$ & & & IOXANE \\
\hline & $\begin{array}{c}\text { WET } \\
\text { METHOD }\end{array}$ & $\begin{array}{c}\text { DRY } \\
\text { METHOD }\end{array}$ & $\begin{array}{c}\text { WET } \\
\text { METHOD }\end{array}$ & $\begin{array}{c}\text { DRY } \\
\text { METHOD }\end{array}$ \\
\hline $5 \% 0.001 \mathrm{M}$ phosphate buffer & .0185 & .02 & .0185 & .02 \\
\hline $2 \%$ water & 2 & & --- & \\
\hline $5 \%$ water & 2 & $2.5,0.5$ & -- & $0.1,0.5$ \\
\hline $10 \%$ water & 2 & - & $-\cdots$ & \\
\hline $2 \% 1 M$ phosphate buffer & buffer ppts & -- & -- & \\
\hline $5 \% 1 \mathrm{M}$ phosphate buffer & 2 & -- & -- & buffer ppts \\
\hline $10 \% 1 \mathrm{M}$ phosphate buffer & - & -- & -- & buffer ppts \\
\hline
\end{tabular}

Note: The dry method is to add dry enryme to solvent and stir at room temperature for 30 minutes.

The wet method is to dissolve the enzyme in the buffer or water, then add the solution in the proportion indicated to the neat DMF or dioxane. 
F1gure 2.2

LACCASE ASSAY VS SYRINGALDAZINE IN $5 \%$ AQEOUS DMF
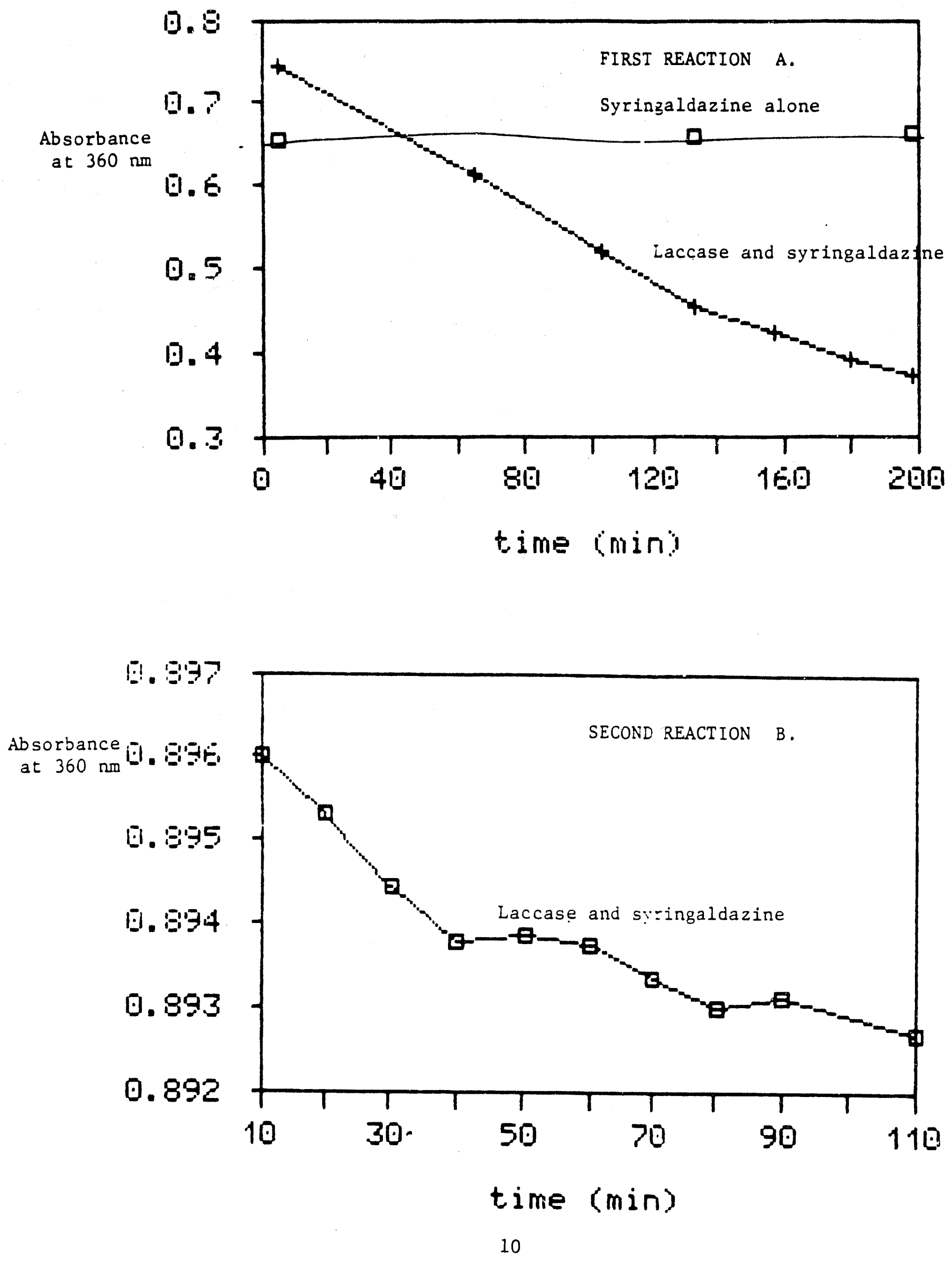
$0.5 \mathrm{ml}$ substrate in media). A $0.001 \mathrm{M}$ phosphate buffer at $\mathrm{pH} 6.5$ was prepared and found to be miscible with the solvents. The following assay conditions were used.

(a) Buffer/Dioxane - The stock syringaldazine was $\left[\begin{array}{llll}1.8 & \times 10^{-4} & \mathrm{M}\end{array}\right]$ in 5 percent buffer/dioxane.

(1) Wet method of enzyme addition - The stock laccase solution was $0.042 \mathrm{mg} / \mathrm{ml}$ in 5 percent dioxane/buffer.

(2) Dry method of enzyme addition - The stock laccase solution as $0.02 \mathrm{mg} / \mathrm{ml}$ in 5 percent dioxane/buffer.

(b) Buffer/DMF - The stock syringaldazine solution was $\left[\begin{array}{llll}2.1 & \times 10^{-4}\end{array}\right.$ $M]$ in 5 percent buffer/DMF.

(1) Wet method of enzyme addition - The stock laccase solution was $0.042 \mathrm{mg} / \mathrm{ml}$ in 5 percent buffer $/ \mathrm{DMF}$.

(2) Dry method of enzyme addition - The stock laccase solution was $0.02 \mathrm{mg} / \mathrm{ml}$ in 5 percent buffer/DMF.

The results of these experiments are shown in graph form in Figures 2.3a-d. The results indicate some activity in both DMF and dioxane.

\subsubsection{Work With Ethylphenylsulfide [EPS] in Organic Media}

EPS is soluble in DMF/buffer and dioxane/buffer. EPS was scanned in 5 percent aqueous DMF and 5 percent aqueous dioxane and the absorbance maxima were: $258 \mathrm{~nm}$ in aqueous dioxane and $272 \mathrm{~nm}$ in aqueous DMF. Unlike the SYN assay, where the product has absorbance at a distinct wavelength in the visible range, changes were observed only in the UV range. Laccase assays were run with EPS as shown below.

The standard assay procedure given in Section 2.2.1 was modified by substituting hydrated dioxane or hydrated DMF for all other solvents (e.g., $3 \mathrm{ml}$ media, $1 \mathrm{ml}$ enzyme in media, $0.5 \mathrm{ml}$ substrate in media). A phosphate buffer at $\mathrm{pH} 6.5$ was prepared and found to be miscible with the solvents. 
F1gure 2.3

A

LACCASE DISSOLVED IN 5\% BUFFER/DIOXANE

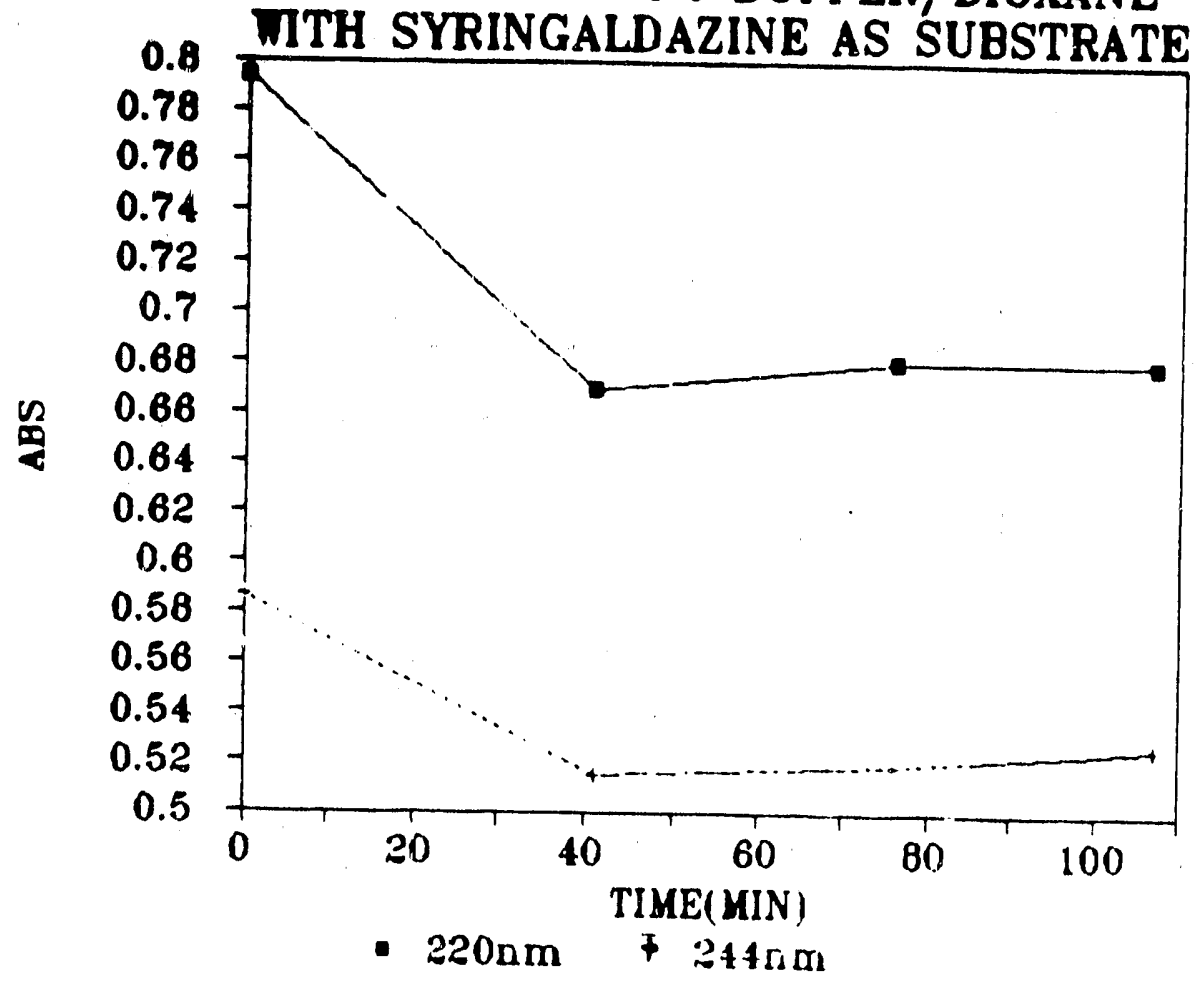

B

LACCASE SUSPENDED IN 5\% BUFFER/DIOXANE

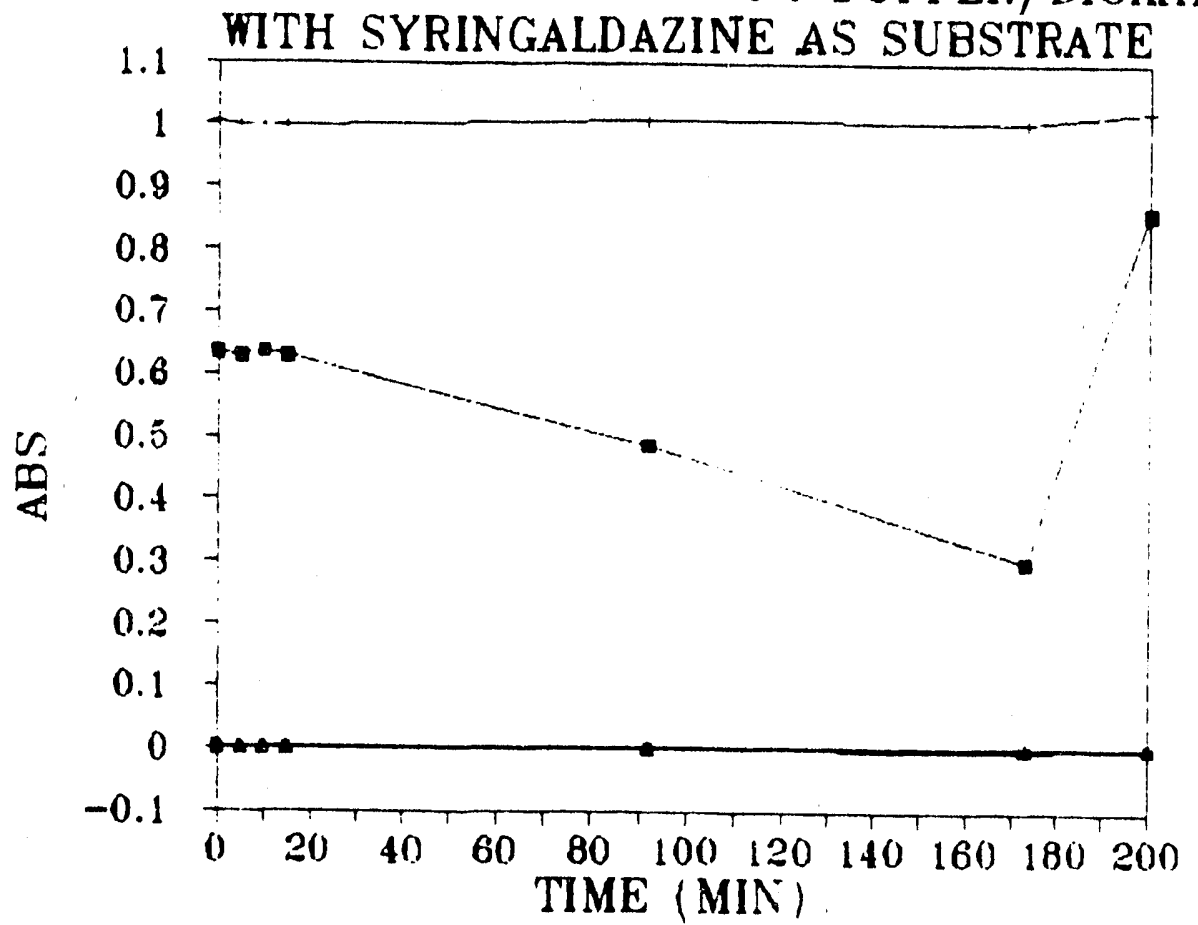

- 220NM - 356NM , 566NM - 646NM * 372NM 
Figure 2.3

C

LACCASE DISSOLVED IN 5\% BUFFER/DMF

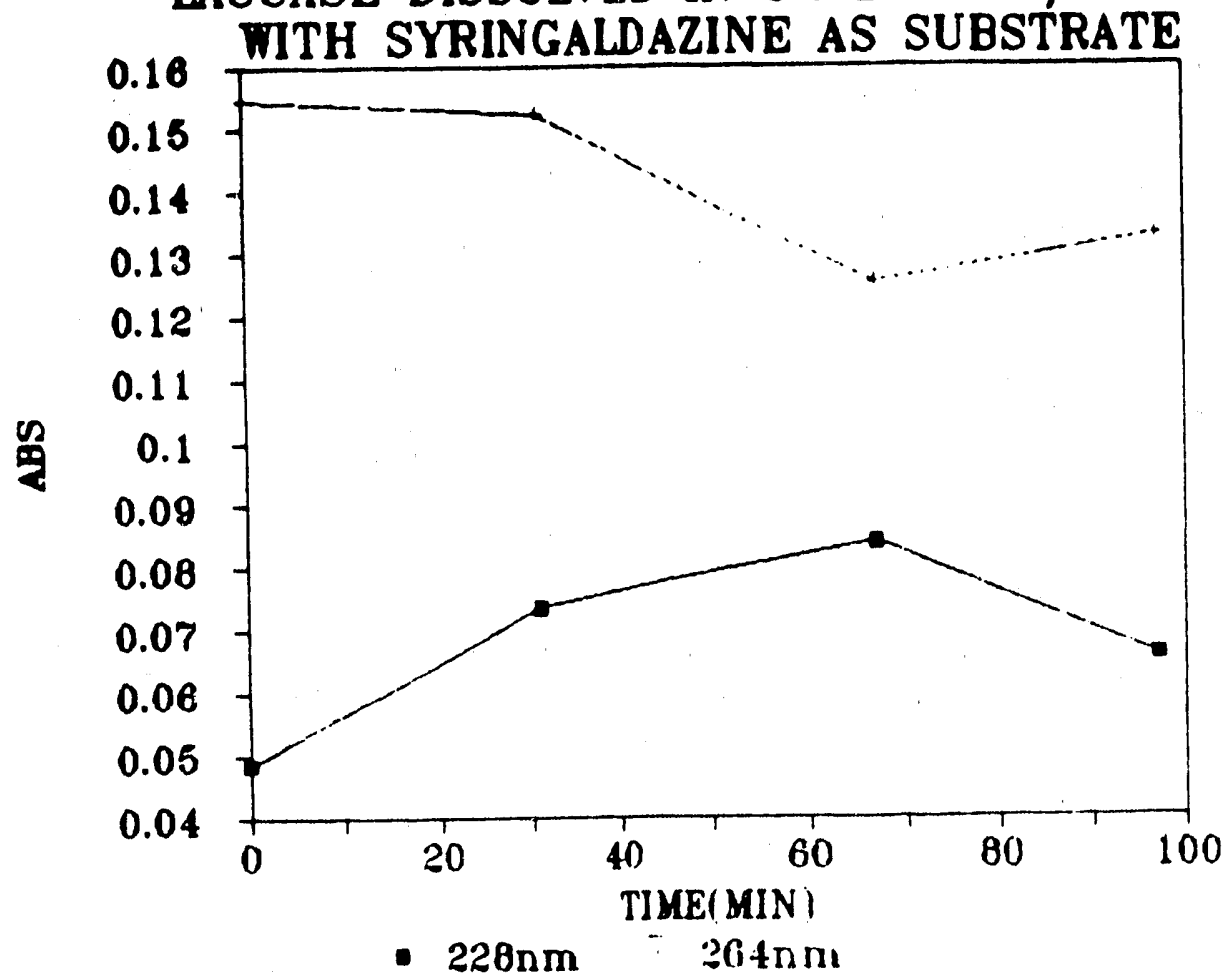

D

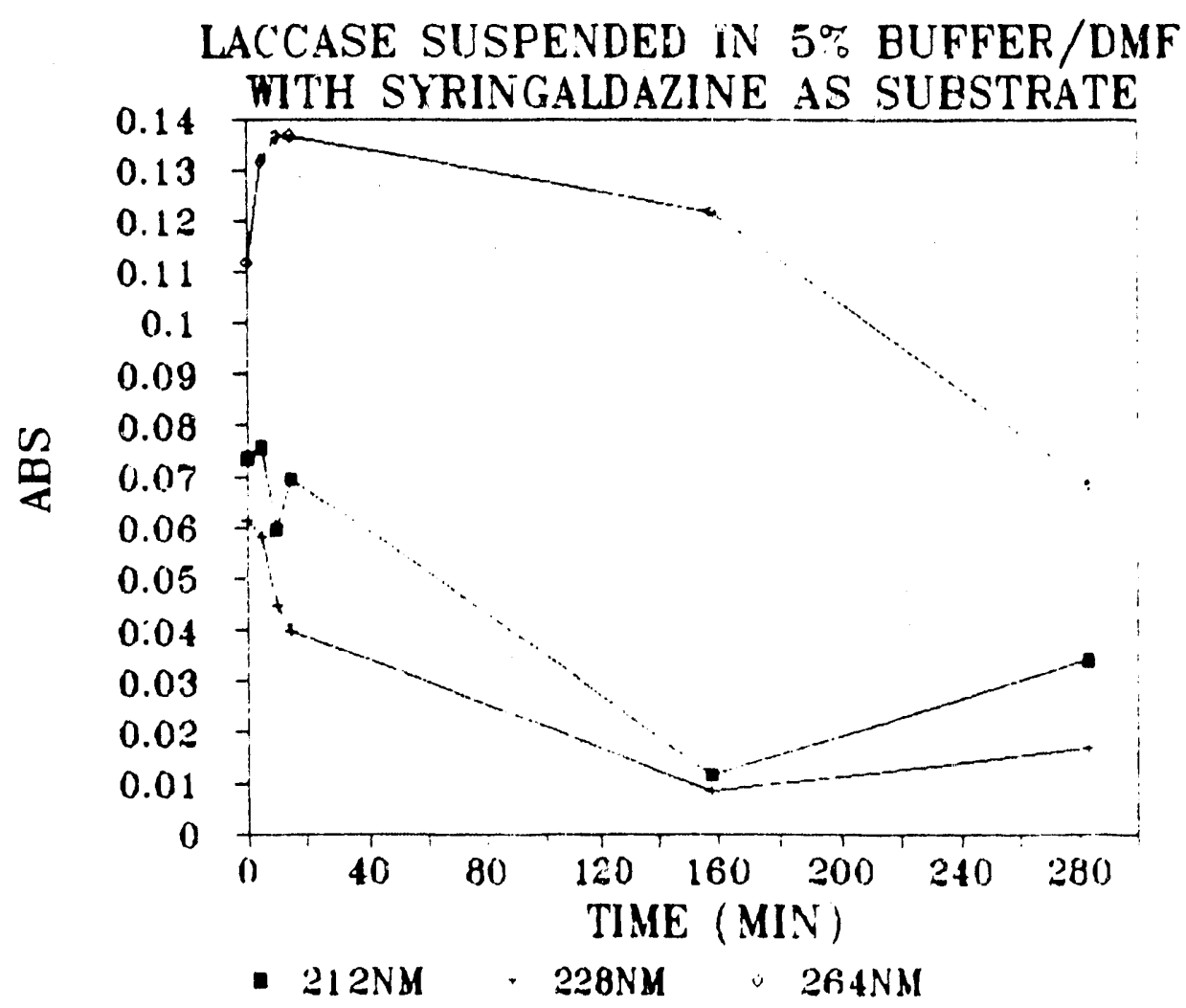


(a) Buffer/Dioxane - The stock EPS solution was $1.38 \times 10^{-3} \mathrm{M}$ in 5 percent buffer/dioxane.

(1) Wet method of enzyme addition - The stock laccase solution was $0.042 \mathrm{mg} / \mathrm{ml}$ in 5 percent buffer/dioxane.

(2) Dry method of enzyme addition - The stock laccase solution was $0.02 \mathrm{mg} / \mathrm{ml}$ in 5 percent buffer/dioxane.

(b) Buffer/DMF - The stock EPS solution was $1.48 \times 10^{-3} \mathrm{M}$ in 5 percent buffer/DMF.

(1) Wet method of enzyme addition - The stock laccase solution was $0.042 \mathrm{mg} / \mathrm{ml}$ in 5 percent buffer/DMF.

(2) Dry method of enzyme addition - The stock laccase solution was $0.04 \mathrm{mg} / \mathrm{ml}$ in 5 percent buffer/DMF.

The results are shown in Figures $2.4 a-c$.

\subsubsection{Work With Dibenzothiophene in Organic Media}

DBT is soluble in DMF/buffer and dioxane/buffer. The standard assay procedure given in Section 2.2 .1 was modified by substituting hydrated dioxane or hydrated DMF for all other solvents $(\mathrm{e} . \mathrm{g} ., 3 \mathrm{ml}$ media, $1 \mathrm{ml}$ enzyme in media, $0.5 \mathrm{ml}$ substrate in media). A phosphate buffer at $\mathrm{pH} 6.5$ was prepared and found to be misclble with the solvents. The following assay conditions were used.

(a) Buffer/Dioxane - The stock DBT solution was $2.78 \times 10^{-4} \mathrm{M}$ in 5 percent buffer/dioxane.

(1) Wet method of enzyme addition - The stock solution of enzyme was $0.042 \mathrm{mg} / \mathrm{ml}$ in 5 percent buffer/dioxane.

(2) Dry method of enzyme addition - The stock solution of enzyme was $0.02 \mathrm{mg} / \mathrm{ml}$ in 5 percent buffer/dioxane.

(b) Buffer/DMF - The stock solution of DBT was $2.17 \times 10^{-4} \mathrm{M}$ in 5 percent buffer/DMF.

(1) Wet method of enzyme addition - The stock solution of laccase was $0.042 \mathrm{mg} / \mathrm{ml}$ solution of laccase in 5 percent buffer/DMF. 
A

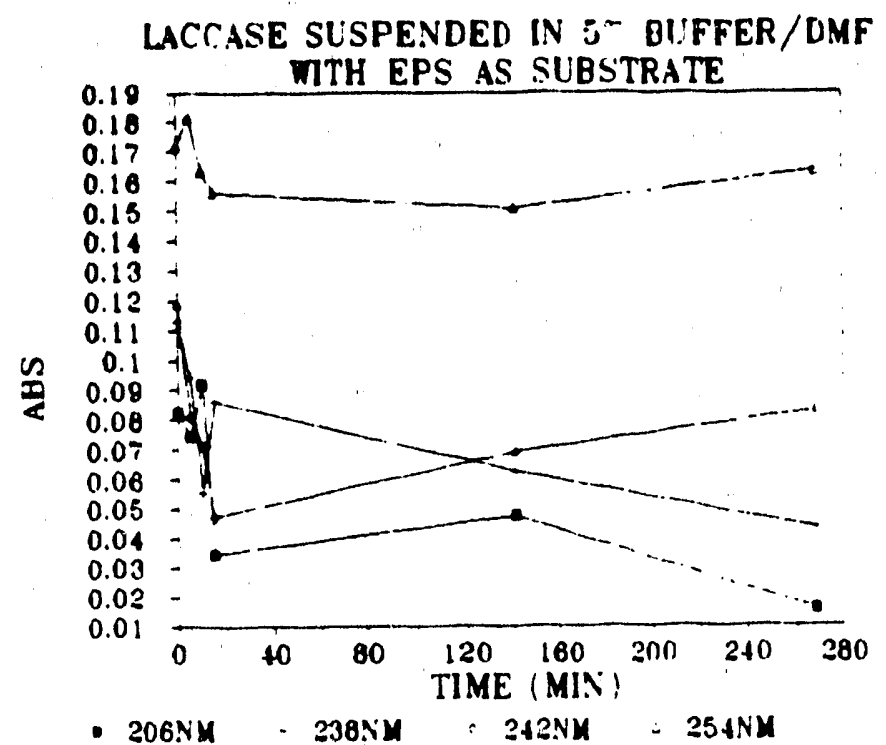

B

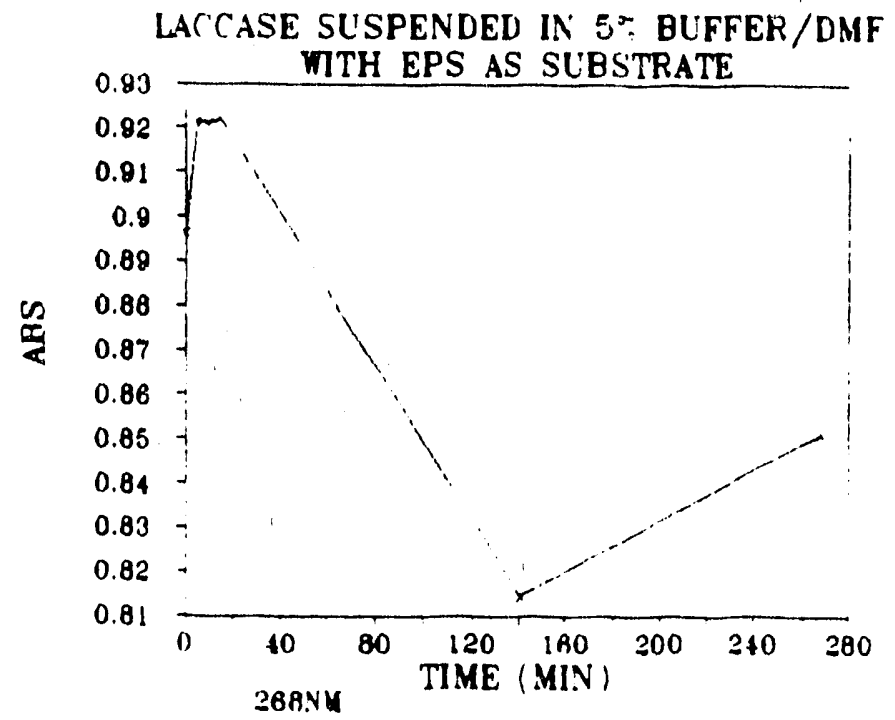

C

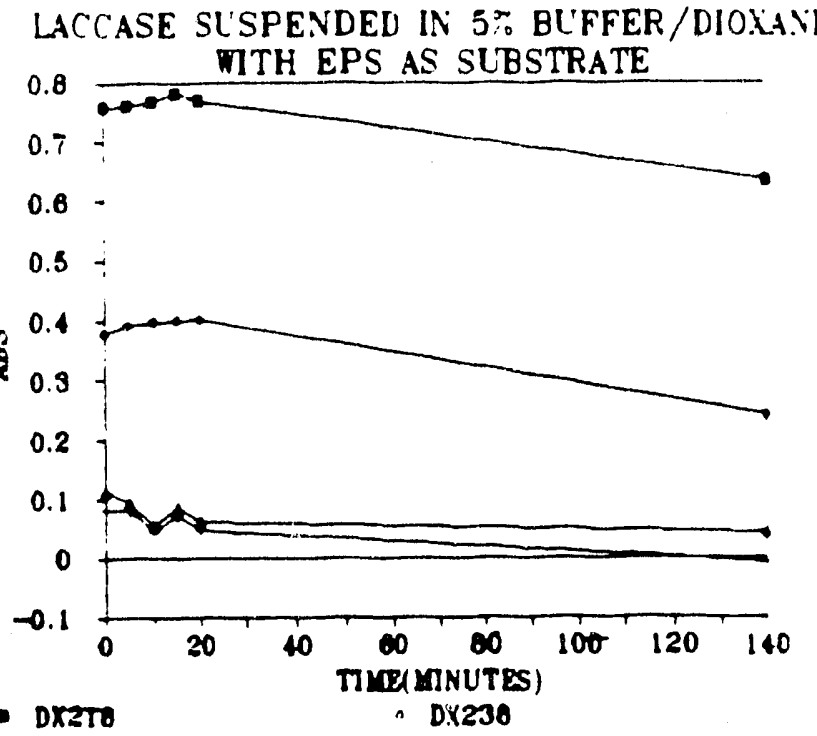


(2) Dry method of enzyme addition - The stock solution of 1accase was $0.02 \mathrm{mg} / \mathrm{ml}$ in 5 percent buf fer/DMF.

The results are shown in Figures $2.5 a-b$.

Unlike the SYN assays, where the product has absorbance at a distinct wavelength in the visible range, $D B T$ and the DBT reaction products with laccase have overlapping spectra in the UV. The interpretation of results, therefore, is more difficult. Although it is clear that activity is seen, the rates of reaction cannot be determined easily. It will be most helpful to utilize the method of gas chromatography to monitor the reaction progress. This topic is discussed in Section 2.3.

\subsection{Gas Chromatography as a Means of Monitoring Substrate Level and Reaction Products}

It has been shown that DBT and EPS can be detected by gas chromatography. A standard curve for DBT at concentrations from 0.2 to $20 \mathrm{mM}$ is shown in Figure 2.6. Below this concentration it is difficult to detect the DBT accurately. The DBT concentration in the assays reported above was somewhat lower than $0.2 \mathrm{mM}$; this low concentration was chosen to facilitate monitoring the reaction progress by UV. For subsequent assays, gas chromatography will be the method of choice for assay monitoring, and a higher concentration of DBT will be employed.

One of the reasons for utilizing gas chromatography is to observe more clearly the change in substiate concentration without interference from new species which are formed in the reaction mixture. It will be particularly useful to know, if possible, the identify of the new species. One possible reaction pathway with DBT degradation is the $4 \mathrm{~S}$ pathway shown in Figure 1.1. Most of these intermediates are commercially available, and we have developed a GC method of assay monitoring which also identifies and quantifies the presence of these compounds.

A Varian 3700 gas chromatograph with a FID detector was fitted with a 3 percent SP2250, 100/120 supelcoport column. The carrier gas was $\mathrm{N}_{2}$ at $30 \mathrm{ml} /$ minute. The column conditions were: detector $=240^{\circ} \mathrm{C}$, injector $=$ 
A

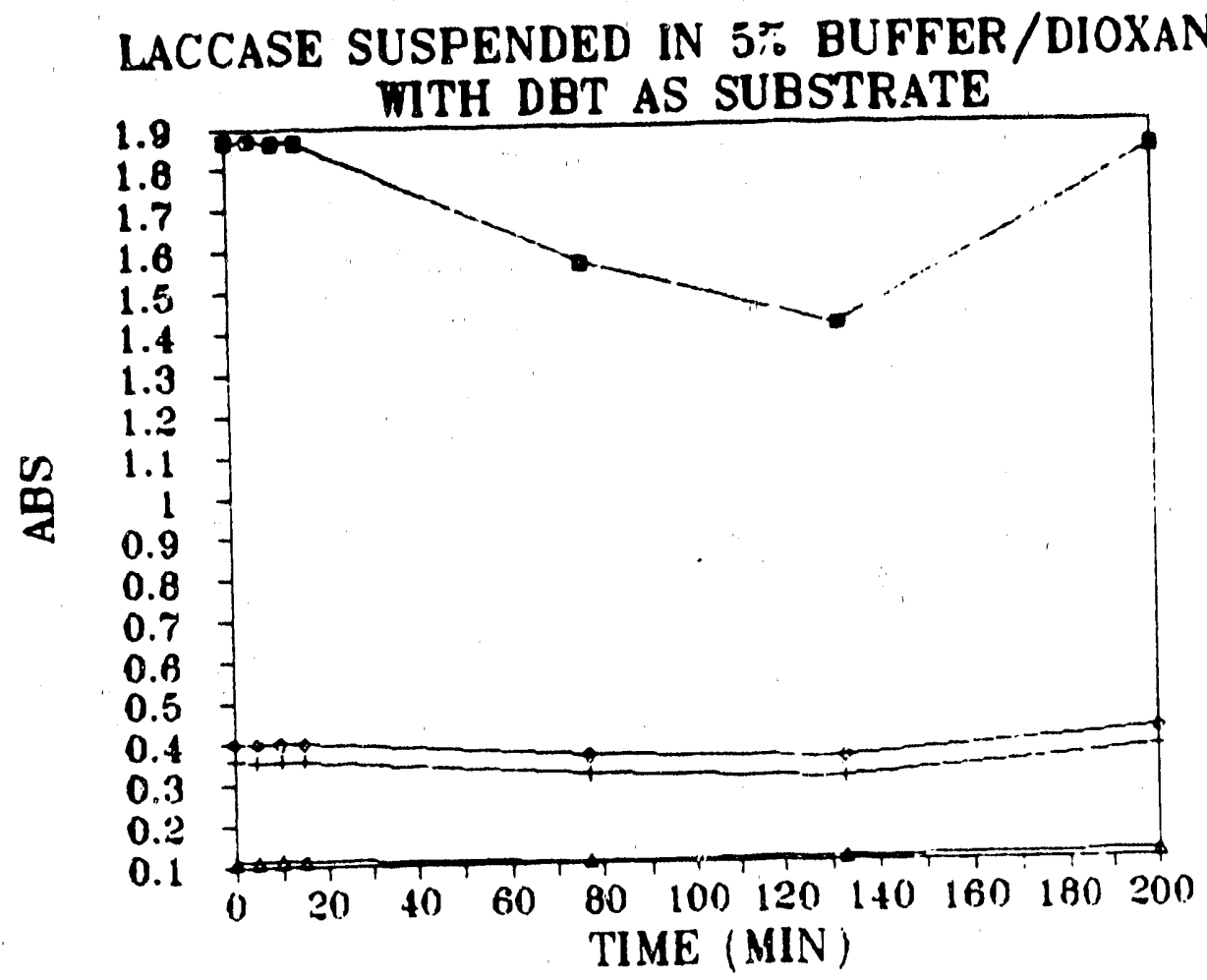

- 238NM+286NM $\because 288 \mathrm{NM}=326 \mathrm{NM}$

LACCASE SUSPENDED IN 5\%BUFFER/DMF WITH DBT AS SIBSTRATE

B

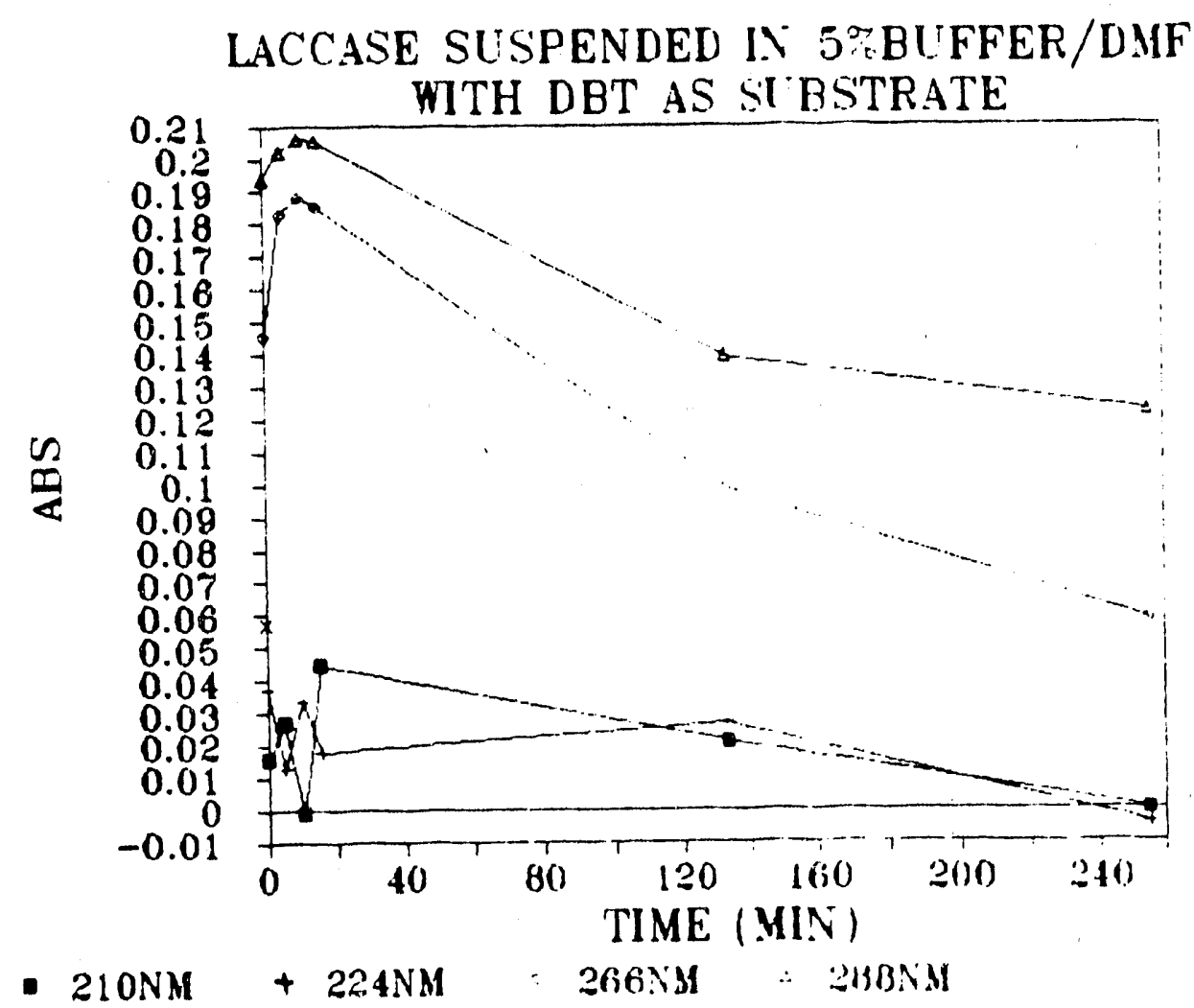




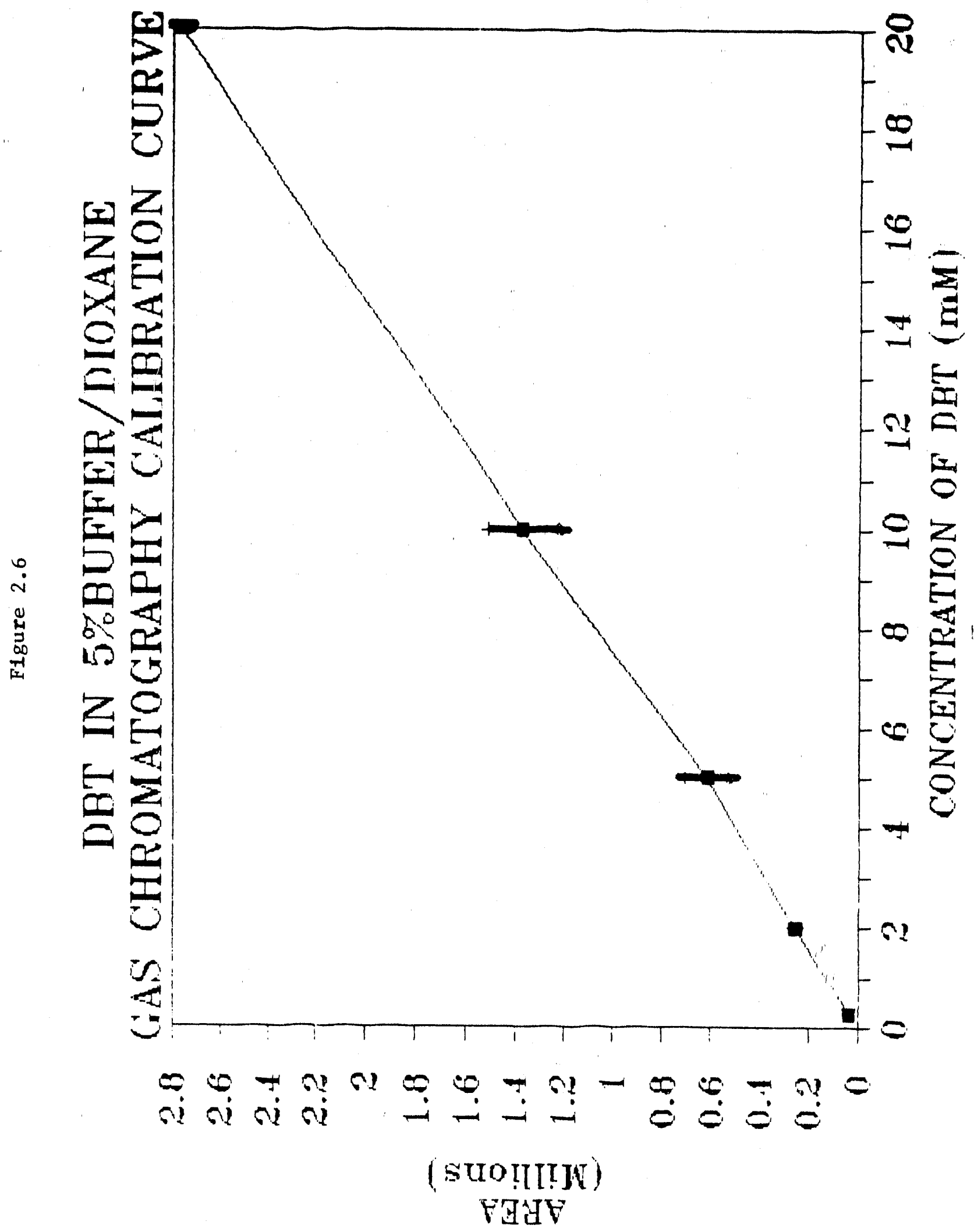


$240^{\circ} \mathrm{C}$. The program was: inftial temperature of $150^{\circ} \mathrm{C}$ for 5 minutes; rise $=$ $2{ }^{\circ} \mathrm{C} /$ minute to $230^{\circ} \mathrm{C}$; hold at $230^{\circ} \mathrm{C}$ for 5 minutes. The attenuation was 1 and the range was 10 to 11. A Varian 4270 integrator was used to record and report the gas chromatograph detector output. In the chromatogram shown in Figure 2.7, $1 \mu 1$ of a mixture of the four compounds. (DBT, DBT sulfoxide, DBT sulfone, and $0,0-b i p h e n o l)$ at concentrations of $5 \mathrm{mM}$ was infected. It should be noted that the sulfoxide solution contained a large portion of the sulfone as well, thus, the sulfoxide peak is relatively small.

\subsection{Spectrophotometric Analysis of DBT and the "4S" Pathway}

As we await the completed installation of our GC/MS systems (currently delayed by bullding electrical problems), we have taken advantage of the spectral properties of DBT and the intermediates and product of the $4 \mathrm{~S}$ pathway (i.e., DBT sulfoxide, sulfone, sulfonate, sulfate, and 2,2-dihydroxybipheno1). As summarized in the spectra shown in Figure 2.8, each of these compounds exhibits a characteristic UV absorption spectrum. Furthermore, each spectral peak can be evaluated by plotting peak height as a function of the experimental matrix.

\subsection{Development of Microbial Sources of Enzyme}

In collaboration with Drs. Holger Jannasch and Dennis Bazylinski, marine microbiologists at the Woods Hole Oceanographic Institute, we have undertaken to identify microbial cultures that can produce enzymes suitable for the desulfurization of coal. This part of our project actually began on August 1, 1988, after Dr. Jannasch returned from his summer field trips.

Eight different sources of microbes were cultured in media providing only DBT or EPA as feedstocks. The results of this first set of studies are shown in Table 2.3. To date, only one of the cultures has exhibited growth on DBT. Dr. Bazylinski's observations of color changes are now being followed up with gas chromatographic analysis, but the colors he has observed suggest that this pool of microbes is metabolizing DBT via ring carbon oxidation. We are continuing to investigate this and other microbial sources of enzymes. 

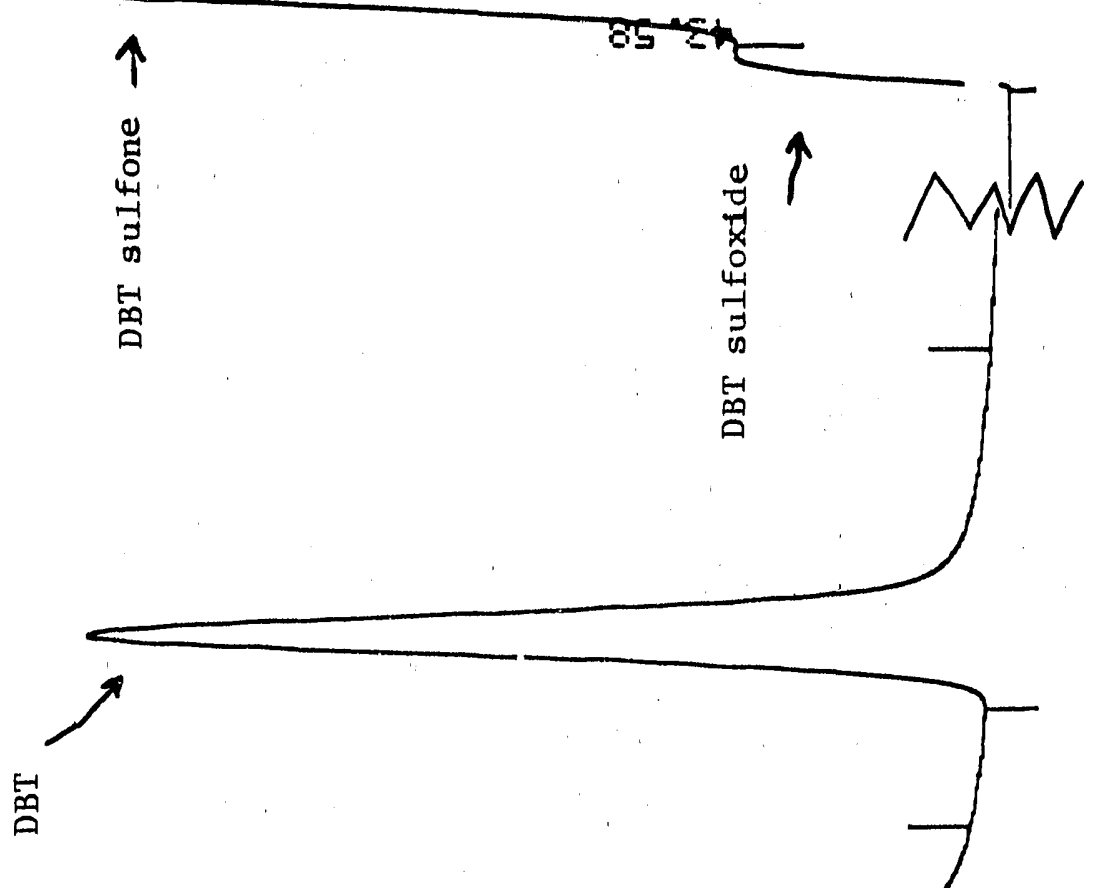

$r$

-

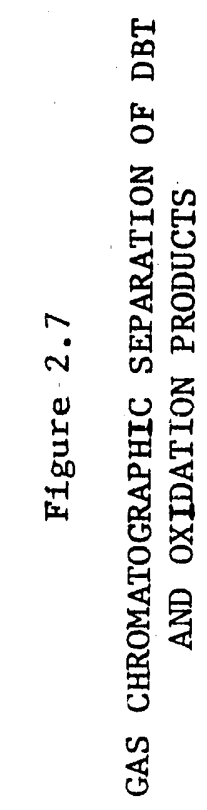

21.
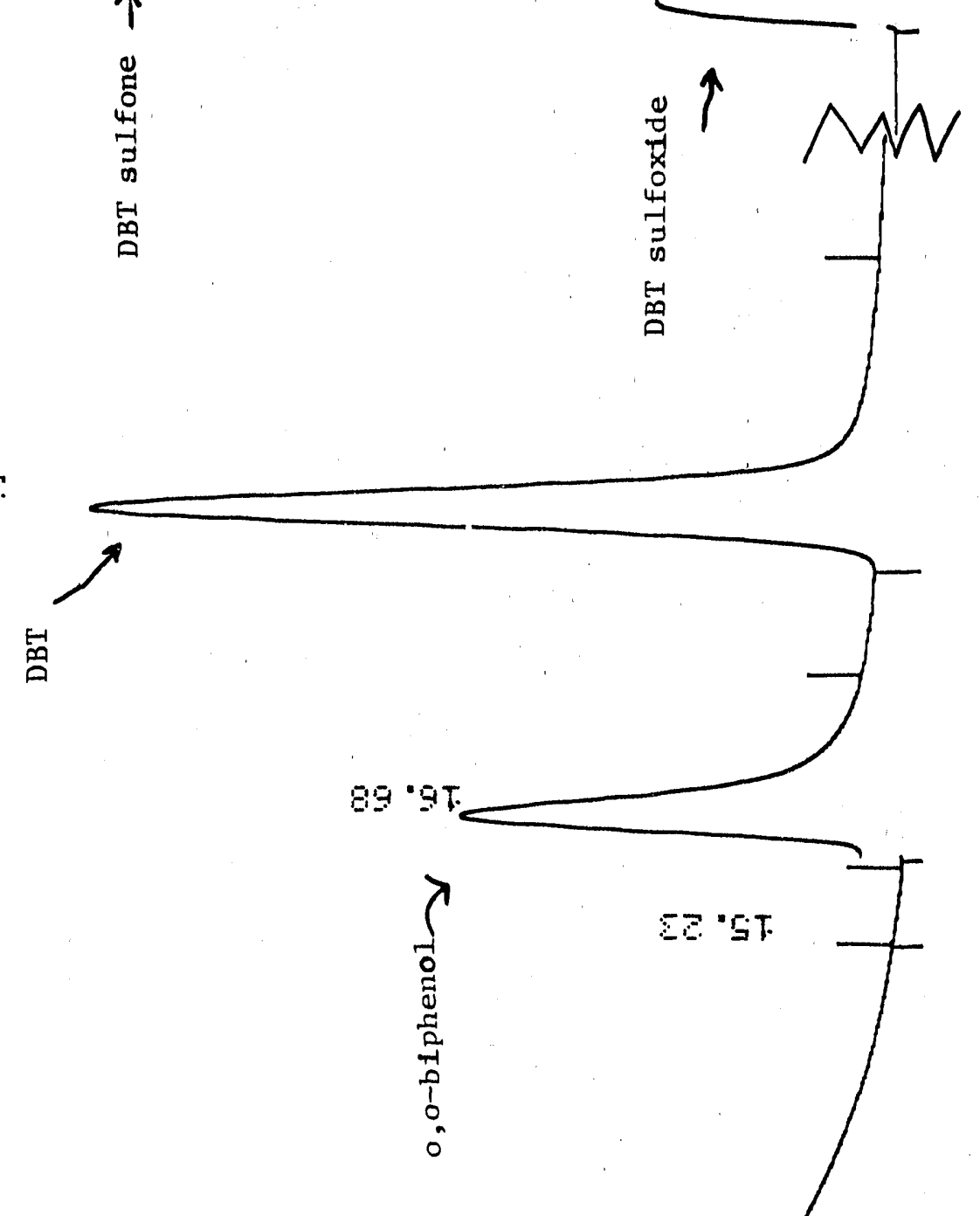

$\infty$
$n$
$n$
$n$

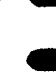

0

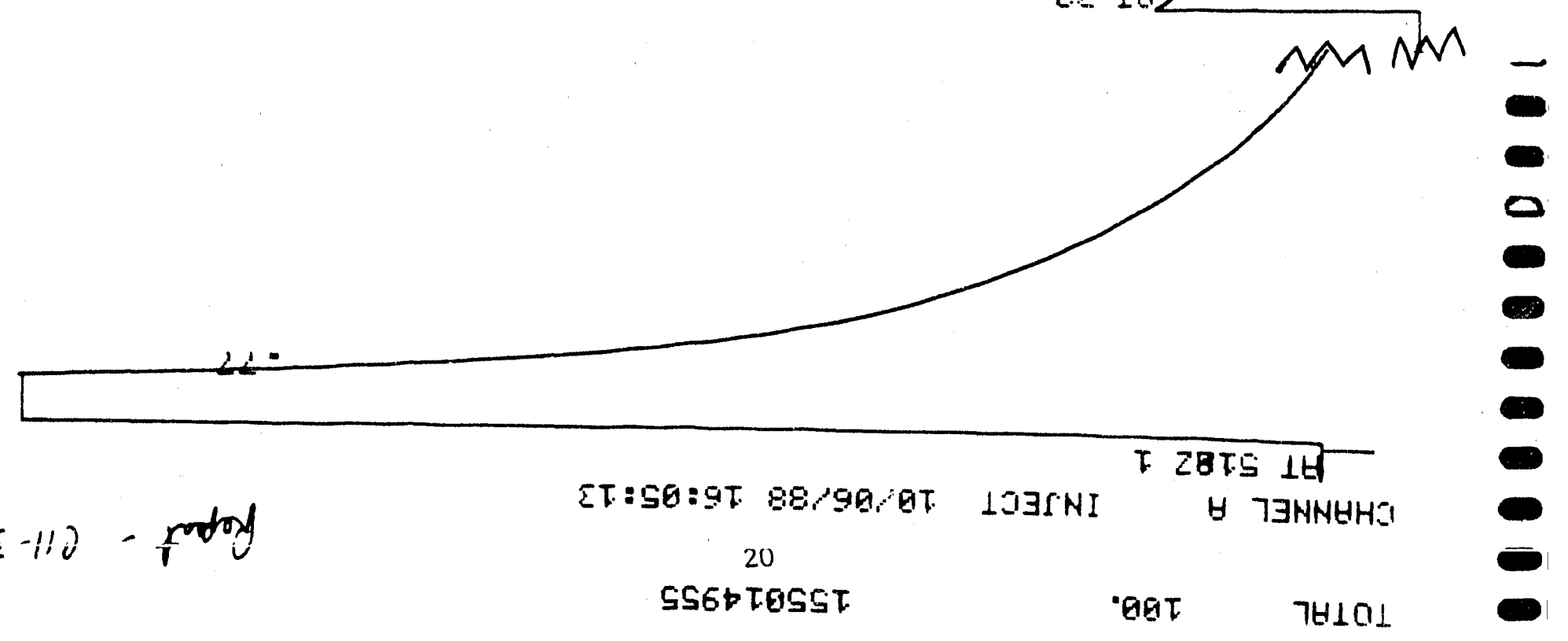




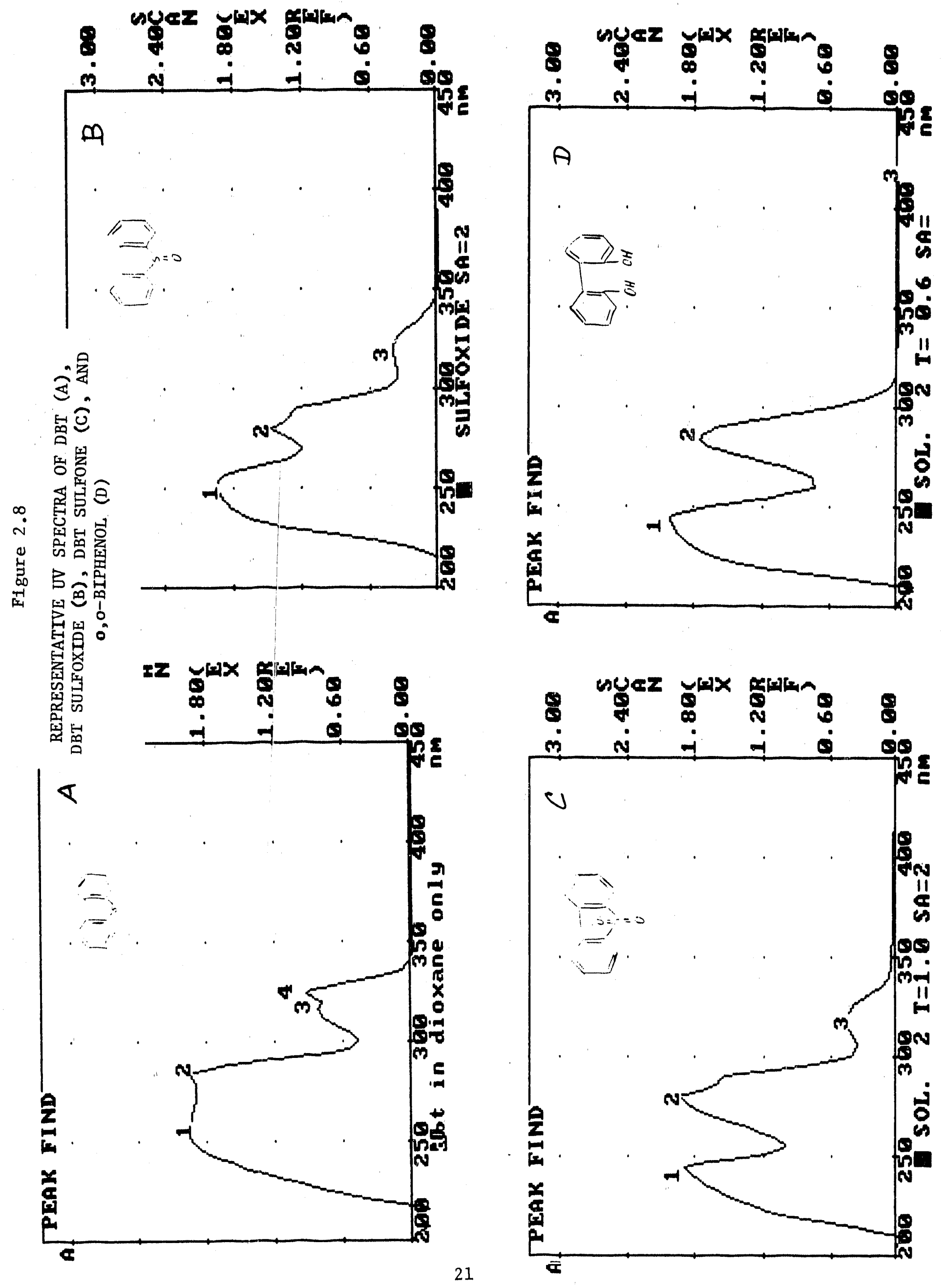


Table 2.3

PRELIMINARY GROWTH DATA FOR EIGHT WEER ENRICHMENT CULTURES GROWN EXCLUSIVELY ON ORGANIC SULFUR FEEDSTOCK

\begin{tabular}{|l|l|l|l|}
\hline SAMPLE DESIGNATION & DBT & EPS \\
\hline (1) 1161 & - & - \\
\hline (2) 1615 & - & - \\
\hline (3) 1966 y-o Mat & - & - \\
\hline (4) 1966 o Mat & - & - \\
\hline (5) 1967 (Top) & - & - \\
\hline (6) 1967 (Middle) & - & - \\
\hline (7) 1967 (Bottom) & $*$ & - \\
\hline (8) 1971 Inj. Core** & - & - \\
\hline
\end{tabular}

In this table, - indicates no growth.

* This enrichment culture turned red after about six weeks. Two weeks later it started turning yellow. It does not fluoresce under wave UV light but the DBT does look different. It will be transferred. Microscopic examination shows viable cells but not a number large enough to indicate an enrichment.

** Inj. Core - Means that DBT was introduced into the mud in-situ at the Guaymes Basin. So this is a very long term incubation. 


\section{Section 3}

\section{PLANS FOR THE SECOND QUARTER}

In the second quarter (October 1 through December 31 ), we w111 continue to seek conditions for promoting the activity of the two enzymes agaisst the two substrates. The methods of analysis will include identification of reaction products. An important aspect of this work will be to chrracterize the stability of the enzymes in the solvent media of interest and in the presence of the DBT and EPS oxidation intermediates and products.

Also, we will be working with the Woods Hole group on the continuation of the microblal screening program. The first phase of their work emphasized utilization of EPS or DBT only in the feedstock. Subsequent work will be with an additional substrate added for co-metabolism. The future work will also broaden the range of organisms examined. 

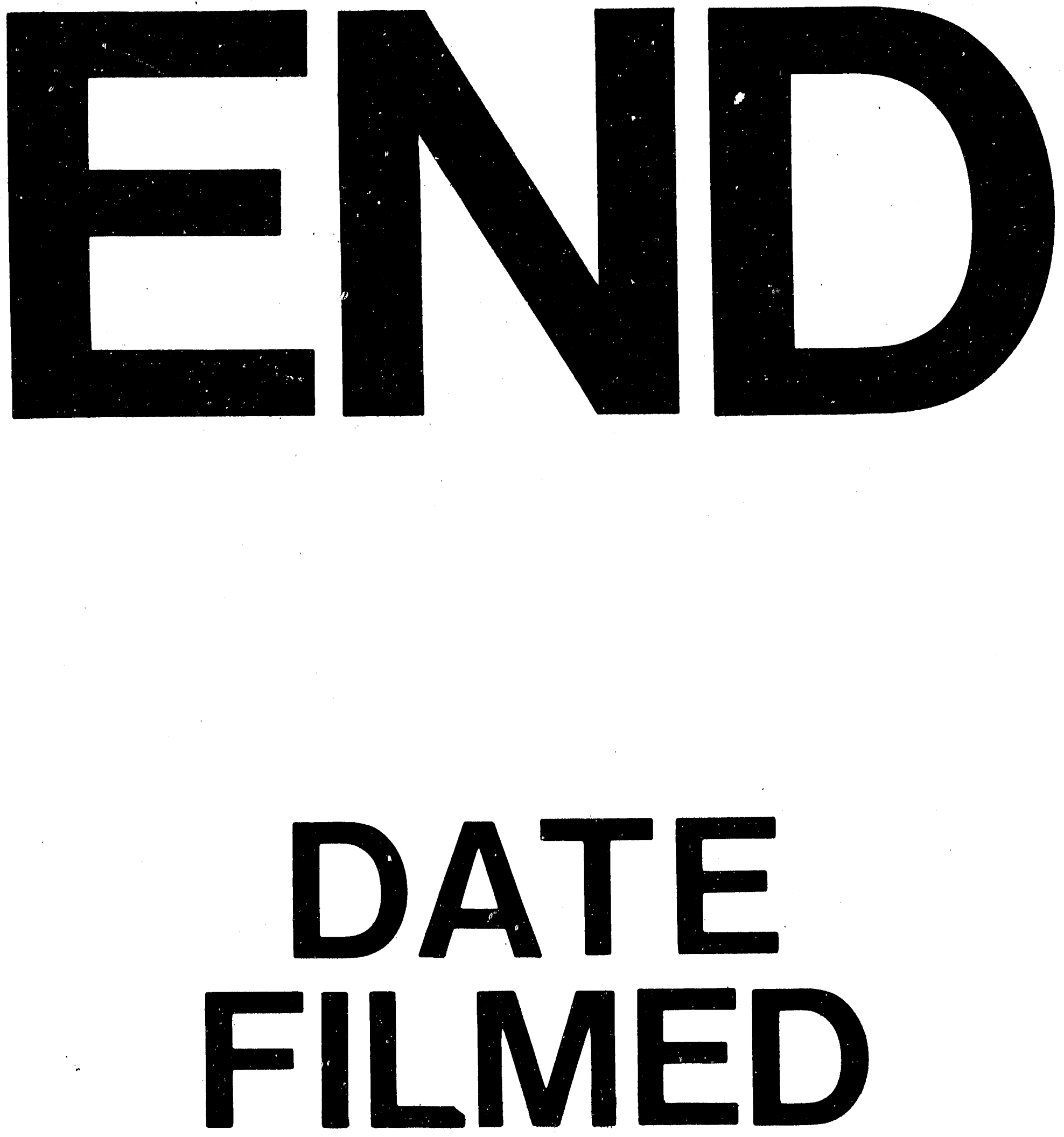

1

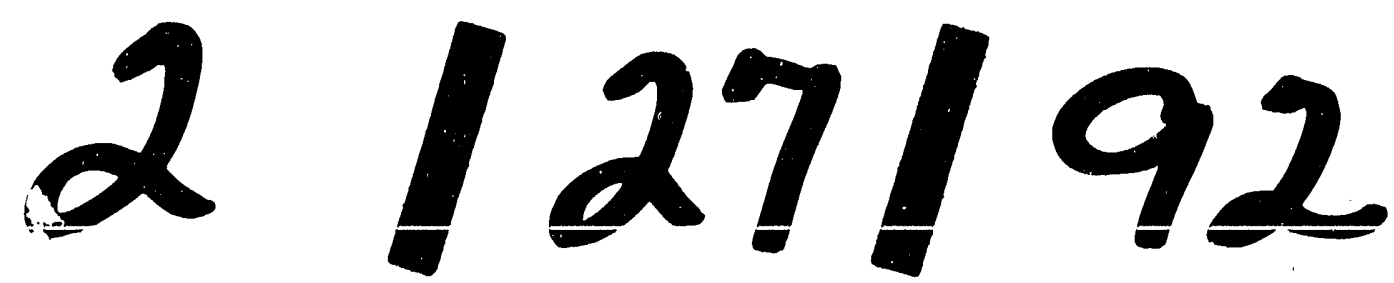


